\title{
Pathogenicity of Pythium Species Associated with Pythium Root Dysfunction of Creeping Bentgrass and Their Impact on Root Growth and Survival
}

\author{
J. P. Kerns and L. P. Tredway, Department of Plant Pathology, North Carolina State University, Campus Box 7616, \\ Raleigh, NC 27695
}

\begin{abstract}
Kerns, J. P., and Tredway, L. P. 2008. Pathogenicity of Pythium species associated with Pythium root dysfunction of creeping bentgrass and their impact on root growth and survival. Plant Dis. 92:862-869.

Symptoms resembling Pythium root dysfunction have been observed on golf course putting greens established with creeping bentgrass across the southeastern United States since 2002. Root isolations from 14 golf courses yielded 59 isolates of Pythium volutum and 16 isolates of Pythium torulosum. Pathogenicity of five isolates of $P$. volutum, two isolates of $P$. torulosum, and a combination of the two species was determined by inoculating mature 'A-1' creeping bentgrass plants. Inoculated plants were incubated for 4 weeks at $24 / 16^{\circ} \mathrm{C}$ (day/night) to permit root infection, then temperatures were increased to $32 / 26^{\circ} \mathrm{C}$ to induce foliar symptoms. No isolates impacted root depth, root mass, or foliar disease severity after 4 weeks at $24 / 16^{\circ} \mathrm{C}$. After increasing the temperature to $32 / 26^{\circ} \mathrm{C}$, isolates of $P$. volutum induced foliar disease severity ranging from 60 to $84 \%$, whereas isolates of $P$. torulosum induced only 14 to $35 \%$ disease. Isolates of $P$. volutum consistently reduced root mass and root depth after 4 weeks at $32 / 26^{\circ} \mathrm{C}$, but $P$. torulosum exhibited no effect. These results demonstrate that $P$. volutum is a pathogen of mature creeping bentgrass plants. Infections that occur during cool weather reduce the growth and survival of creeping bentgrass roots during hot weather and give rise to foliar symptoms.
\end{abstract}

Creeping bentgrass (Agrostis palustris Huds.) is a cool-season grass species that is widely planted on golf courses in temperate and subtropical climates. This is the preferred turfgrass species for golf course greens because it tolerates extremely close mowing and produces a fast, uniform putting surface (19). Creeping bentgrass is not well-adapted to the persistent hot and humid conditions experienced during summer months in the southeastern United States, which often results in reduced plant vigor and increased susceptibility to disease. In addition, most putting greens are constructed with artificial root zones containing 85 to $100 \%$ sand and 0 to $15 \%$ organic matter by volume to facilitate rapid drainage and drying of the playing surface. These root zones have extremely low water- and nutrient-holding capacities (19). While these construction practices may reduce the development of fungal diseases that are encouraged by wet soil conditions, they may also enhance other diseases that are encouraged by physiological stress.

Despite the importance of creeping bentgrass to the golf course industry, few root diseases have been described and

Corresponding author: James P. Kerns

E-mail: jpk@plantpath.wisc.edu

Accepted for publication 15 January 2008.

doi:10.1094/PDIS-92-6-0862

(C) 2008 The American Phytopathological Society thoroughly researched on this host. Takeall patch, caused by Gaeumannomyces graminis var. avenae, is a common disease of creeping bentgrass in temperate climates but is not widely distributed in the subtropical climates of the southeastern United States (15). Summer patch, caused by Magnaporthe poae, was originally observed in creeping bentgrass in Florida in 1987 (4) and was recently documented in North Carolina (16). Two Pythium-induced root diseases have been described in creeping bentgrass: Pythium root rot $(1,6,12)$ and Pythium root dysfunction (PRD) $(5,8)$. However, the etiology, epidemiology, and management of these Pythium diseases remain poorly understood.

Pythium root rot is characterized by a crown and root decline that results in chlorotic turfgrass plants with reduced vigor and density. Roots and stolons are necrotic and generally have a water-soaked appearance. Stand symptoms are typically nondescript; yet small yellow or necrotic patches may occur on creeping bentgrass after prolonged wet conditions (12). Abad et al. (1) isolated 33 Pythium species from roots and crowns of creeping bentgrass exhibiting symptoms of root and crown rot in North Carolina. Eight species were classified as highly virulent to creeping bentgrass seedlings at 28 and $32^{\circ} \mathrm{C}$, which included $P$. arrhenomanes, $P$. aristosporum, $P$. aphanidermatum, $P$. graminicola, $P$. myriotylum, $P$. tardicrescens, $P$. vanterpoolii, and $P$. volutum. However, the most frequently isolated species were $P$. torulosum, $P$. catenulatum, $P$. arrhenomanes, and $P$. vanterpoolii.

PRD of creeping bentgrass was first described by Hodges and Coleman in 1985 (8). They observed that newly established, high-sand content ( $>60 \%$ sand) putting greens were rapidly killed during the summer. $P$. aristosporum and $P$. arrhenomanes were consistently isolated from diseased roots, and were highly virulent toward the secondary roots of creeping bentgrass. Diseased roots exhibited a yellowish tan discoloration compared to uninfected roots. Root tips were described as bulbous and were ultimately killed.

Feng and Dernoeden (5) identified eight Pythium species in a collection of 28 isolates from 109 putting green samples exhibiting symptoms of PRD: $P$. aristosporum, $P$. aphanidermatum, $P$. catenulatum, $P$. graminicola, $P$. torulosum, $P$. vanterpoolii, $P$. volutum, and $P$. ultimum var. ultimum. Most of the isolates were obtained from putting greens that were less than 3 years old. $P$. aristosporum and $P$. aphanidermatum were highly virulent toward creeping bentgrass seedlings at 18 and $28^{\circ} \mathrm{C}$, but $P$. volutum was only highly virulent at $18^{\circ} \mathrm{C}$. P. aristosporum was isolated three times, whereas $P$. aphanidermatum and $P$. volutum were only isolated once from 109 putting green samples. The remaining species were either nonpathogenic or exhibited low to moderate virulence. Based on the frequency of isolation and pathogenicity experiments, it was concluded that $P$. aristosporum was the most important causal agent of PRD in the mid-Atlantic region of the United States.

Symptoms characteristic of PRD have been observed on creeping bentgrass putting greens throughout the southeastern United States since 2002. The foliar symptoms of PRD initially appear as wilt, drought stress, or chlorosis in distinct, circular patches ranging from 6 to $30 \mathrm{~cm}$ in diameter. If the disease is left uncontrolled, foliar symptoms progress to a yelloworange dieback, and much of the turf may eventually die. Affected roots are a lighttan color with bulbous root tips and have few root hairs. The most severely affected greens are typically less than 6 years old and have root zones constructed of 85 to $100 \%$ sand and 0 to $15 \%$ organic matter by volume. Symptoms are most commonly observed during hot weather in summer, but may also be seen during warm, dry conditions in fall, winter, or spring. Root 
depth is often not negatively impacted during the fall and spring, yet root depth is significantly reduced in affected patches during the summer months. $P$. volutum was consistently isolated from diseased root tissue in North Carolina and was demonstrated to be highly virulent toward mature creeping bentgrass roots in controlled environments (9).

Hodges and Coleman (8) recognized the importance of inoculating mature turfgrass plants and were able to reproduce PRD symptoms in the greenhouse by inoculating the secondary roots originating from creeping bentgrass stolons. Prior to our discovery of $P$. volutum as a causal agent of PRD in North Carolina (9), this species was isolated infrequently from turfgrasses exhibiting symptoms of root rot and root dysfunction $(1,5)$. Inoculations in both studies were performed on creeping bentgrass seedlings; thus the impact of $P$. volutum on mature creeping bentgrass plants and secondary root growth remains unknown.

Although the expression of PRD symptoms is most common in summer, when creeping bentgrass is subjected to persistent heat stress, our observations indicate that $P$. volutum is not highly active under these conditions. Instead, the majority of hyphal growth and oospore production, and root infection, are observed during the fall, winter, and spring, coinciding with the time when creeping bentgrass roots are most actively growing. These observations are consistent with the results of Feng and Dernoeden (5), who showed that $P$. volutum was highly virulent toward creeping bentgrass seedlings at $18^{\circ} \mathrm{C}$ but only slightly virulent at $28^{\circ} \mathrm{C}$. It is unknown if $P$. volutum infections reduce the regrowth of creeping bentgrass roots during the fall and spring, reduce root survival during hot weather, or simply reduce the root's ability to absorb water and nutrients from the soil solution.
To further improve our ability to diagnose and manage root diseases in creeping bentgrass, additional research is needed to determine the distribution of Pythium species causing PRD in sand-based root zones. The objectives of this study were to (i) determine the distribution of Pythium species causing PRD in North Carolina and neighboring states; (ii) determine the pathogenicity and virulence of Pythium species on mature creeping bentgrass plants; and (iii) assess the impact of $P y$ thium species on the growth of creeping bentgrass roots during cool weather and their survival during hot weather.

\section{MATERIALS AND METHODS}

Isolation and identification of Pythium species. Isolates of Pythium $(n=75)$ were obtained from creeping bentgrass putting greens exhibiting symptoms of PRD between September 2003 and April 2005. Samples were obtained from 11 locations in North Carolina and one location in Virginia (Table 1). S. B. Martin (Clemson University) provided one isolate from Guilford County, NC, four isolates from
South Carolina, and three isolates from Georgia (Table 1).

Roots with a significant amount of $P y$ thium hyphae and oospores $(>10)$ were tan, lacked root hairs, and possessed bulbous root tips. Sections of roots $(1 \mathrm{~cm})$ exhibiting these symptoms were washed under continuously flowing tap water for at least $6 \mathrm{~h}$ and rinsed in sterile deionized water. Infected roots were blotted dry with sterile paper towels and placed on PARP medium (11), clarified V8 juice cholesterol agar (SV8) (11), or were baited with creeping bentgrass seedlings. Baiting was performed by placing washed root sections in the root zone of 'A-4' creeping bentgrass seedlings grown in calcined clay (Turface Allsport, Profile Products LLC, Buffalo Grove, IL), incubating in a saturated condition at room temperature for 5 to 7 days, washing the infected seedling roots as described above, and plating on SV8. After incubation for 3 days in the dark at $18^{\circ} \mathrm{C}$, colonies resembling Pythium were transferred to a fresh plate of SV8. If bacterial contamination occurred, isolates were purified by placing mycelial plugs under a

Table 2. Designation of internal transcribed spacer (ITS) haplotype, type isolate, number of isolates per haplotype, and morphological characteristics of Pythium volutum and P. torulosum

\begin{tabular}{llclcc}
\hline $\begin{array}{l}\text { ITS } \\
\text { haplotype }^{\mathbf{x}}\end{array}$ & Type isolate $^{\mathbf{y}}$ & $\begin{array}{c}\text { Isolates in } \\
\text { haplotype }\end{array}$ & $\begin{array}{c}\text { Arrangement } \\
\text { of antheridia }\end{array}$ & $\begin{array}{c}\text { No. of } \\
\text { antheridia }\end{array}$ & $\begin{array}{c}\text { Average diameter } \\
\text { of oogonium }^{\mathbf{z}}\end{array}$ \\
\hline PV1 & PRD3 & 1 & Diclinous & 6 & $28.7 \pm 2.1$ \\
PV2 & PRD6 & 1 & Diclinous & 7 & $31.2 \pm 1.7$ \\
PV3 & PRD11 & 1 & Diclinous & 5 & $30.4 \pm 1.2$ \\
PV4 & OC2, PRD48 & 41 & Diclinous & 7 & $28.1 \pm 3.2$ \\
PV5 & OC11 & 1 & Diclinous & 6 & $26.6 \pm 1.1$ \\
PV6 & PRD38,39 & 14 & Diclinous & 5 & $30.1 \pm 2.6$ \\
PT1 & SV3 & 8 & Monoclinous & 1 & $17.4 \pm 1.1$ \\
PT2 & PV3 & 6 & Monoclinous & 1 & $16.1 \pm 1.7$ \\
PT3 & GO1 & 1 & Monoclinous & 1 & $14.9 \pm 1.9$ \\
PT4 & PRD20 & 1 & Monoclinous & 1 & $18.2 \pm 1.4$ \\
\hline
\end{tabular}

x $\mathrm{PV}=$ P. volutum $; \mathrm{PT}=$ P. torulosum.

y Isolate depicted in phylogram.

${ }^{\mathrm{z}}$ Diameter in micrometers based on measurement of 20 oospores per isolate, average and standard deviation calculated using the number of isolates in each haplotype.

Table 1. Origin of Pythium isolates, creeping bentgrass variety planted and year of putting green construction, plating method and medium, number of $P y$ thium isolates collected at each location, and prevalence of $P$. volutum and P. torulosum

\begin{tabular}{|c|c|c|c|c|c|c|}
\hline Golf course & $\begin{array}{l}\text { Variety / year } \\
\text { constructed }\end{array}$ & Isolation method & Isolation media & No. of isolates & $\begin{array}{c}\text { No. of } \\
\text { P. volutum }\end{array}$ & $\begin{array}{c}\text { No. of } \\
\text { P. torulosum }\end{array}$ \\
\hline 1. Greensboro, NC & Cato:Crenshaw / 1996 & Direct plating & PARP & 1 & 0 & 1 \\
\hline \multirow[t]{2}{*}{ 2. Chapel Hill, NC } & A-1:A-4 / 2002 & Direct plating & PARP & 7 & 0 & 7 \\
\hline & & & $\mathrm{SV} 8^{\mathrm{z}}$ & 9 & 9 & 0 \\
\hline 3. Stanley, NC & A-4 / 2002 & Baiting & PARP w/iprodione & 7 & 4 & 3 \\
\hline 4. Wilmington, NC & A-1:A-4 / 2003 & Direct plating & PARP & 1 & 0 & 1 \\
\hline 5. Graniteville, SC & A-1 / 2000 & Direct plating & PARP & 4 & 1 & 3 \\
\hline 6. Durham, NC & A-1:A-4 / 2001 & Baiting & SV8 & 11 & 11 & 0 \\
\hline \multirow[t]{2}{*}{ 7. Charlotte, NC } & A-1 / 2000 & Direct plating & SV8 & 4 & 4 & 0 \\
\hline & & Baiting & PARP & 6 & 6 & \\
\hline 8. Roanoke, VA & L-93 / 2000 & Direct plating & PARP & 8 & 8 & 0 \\
\hline 9. Durham, NC & A-1:A-4 / 2001 & Direct plating & PARP & 2 & 2 & 0 \\
\hline 10. Charlotte, NC & L-93 / 1996 & Direct plating & PARP & 1 & 1 & 0 \\
\hline 11. Hampstead, NC & L-93 & Direct plating & PARP & 1 & 1 & 0 \\
\hline 12. Statesville, NC & L-93 / 2002 & Direct plating & SV8 & 3 & 3 & 0 \\
\hline 13. Charlotte, NC & G-2 / 2000 & Direct plating & SV8 & 2 & 2 & 0 \\
\hline 14. Pinehurst, NC & G-2 / 1998 & Direct plating & SV8 & 6 & 6 & 0 \\
\hline \multirow[t]{2}{*}{ 15. Augusta, GA } & Unknown & Direct plating & PARP & 2 & 1 & 1 \\
\hline & & & Totals & 75 & 59 & 16 \\
\hline
\end{tabular}

${ }^{\text {z }}$ SV8 = clarified V8 juice cholesterol agar. 
block of fresh PARP medium. Mycelium growing through the top of the medium was then transferred to a fresh plate of SV8. Working cultures were maintained on SV8. For long-term storage of isolates, 10 mycelial plugs cut from a 4-day-old SV8 culture were placed in a test tube containing $10 \mathrm{ml}$ of sterile deionized water and stored at $10^{\circ} \mathrm{C}(11)$.

Morphological identification of $P \boldsymbol{y}$ thium species. All isolates identified as a Pythium species were transferred to grassleaf cultures to induce production of spo- rangia, antheridia, oogonia, and oospores. Four to six $1 \mathrm{~cm}^{2}$ mycelial plugs were placed in a sterile petri dish containing 20 $\mathrm{ml}$ of sterile deionized water and 10 to 15 pieces $(\sim 1.5 \mathrm{~cm}$ long) of autoclaved (30 min) creeping bentgrass leaves $(1,11)$. The grass-leaf cultures were incubated at room temperature under continuous fluorescent light for 3 to 4 days. All isolates produced sporangia, antheridia, oogonia, and oospores in the grass-leaf cultures. Pythium species were identified using the keys and descriptions of van der Plaats-Niterink (20) and Dick (3). Identification was based on the morphology and dimensions of 20 arbitrarily selected reproductive structures and colony morphology on SV8, water agar, and corn meal agar. Ten isolates also were sent to the Plant Pathogen Identification Laboratory at North Carolina State University to confirm identification.

Phylogenetic analysis using ribosomal DNA sequences. Each isolate was grown for 7 days at room temperature (23 to $25^{\circ} \mathrm{C}$ ) in $2 \mathrm{ml}$ of potato dextrose broth (Difco, Lawrence, KS). The mycelial sus-
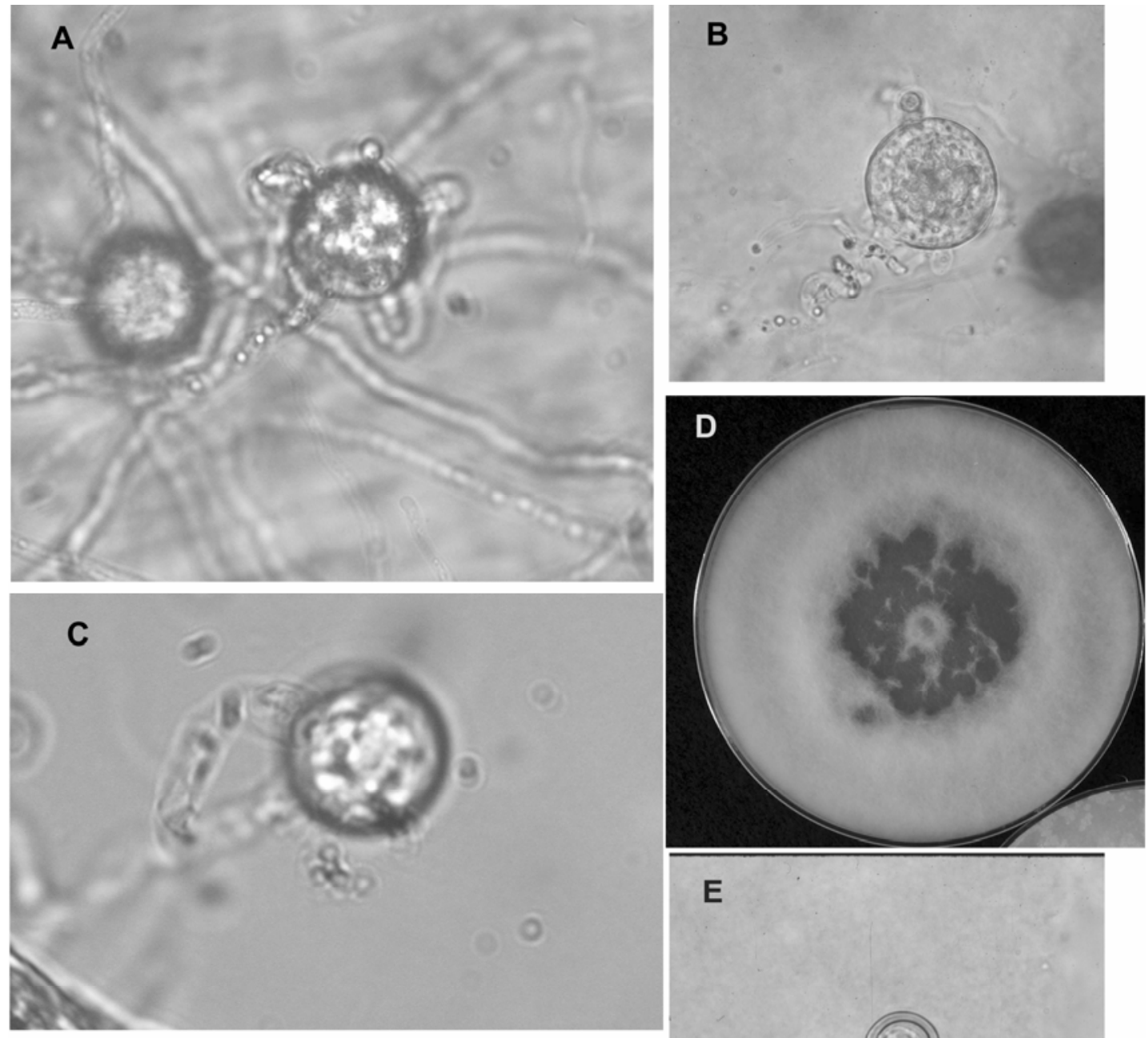

E
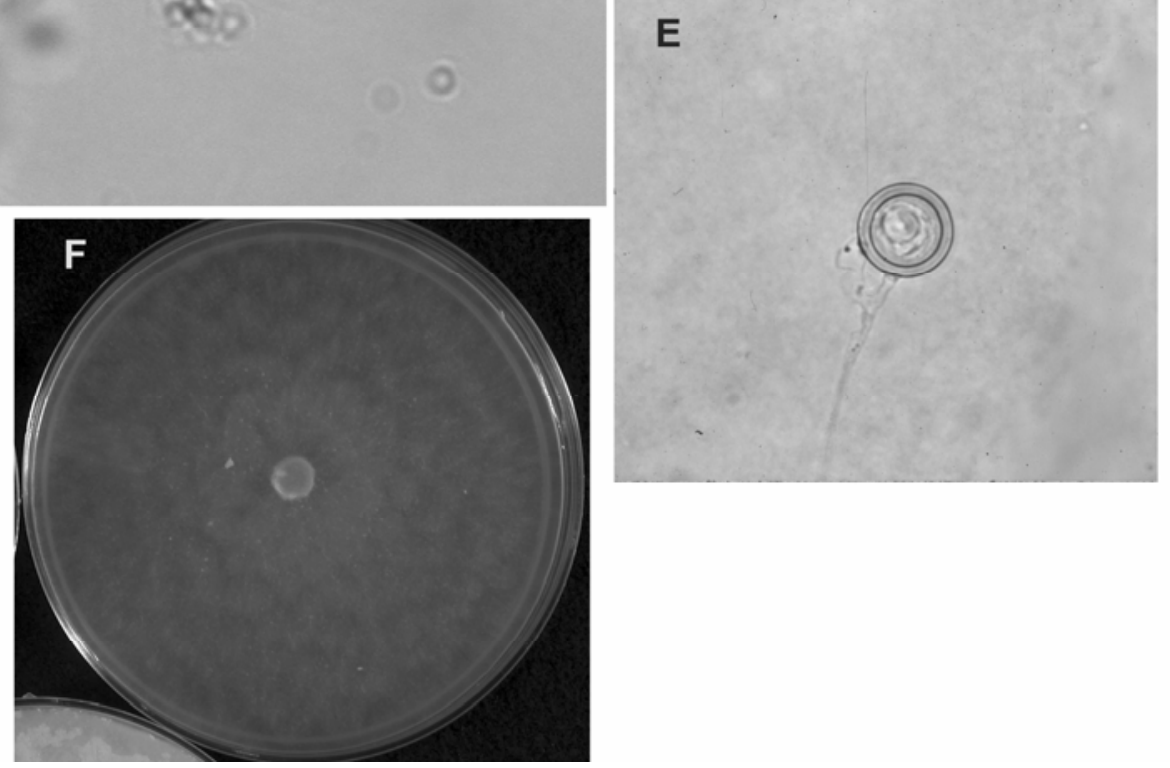

Fig. 1. Antheridial and oospore characteristics and colony morphology of Pythium volutum and P. torulosum. A, P. volutum oogonium with multiple diclinous antheridia. B, P. volutum oogonium with antheridium coiling around oogonial stalk. C, $P$. torulosum plerotic oospore. D, P. volutum colony morphology. E, P. torulosum oogonium with monoclinous antheridium. F, P. torulosum colony morphology. 
pension was transferred to a $1.5-\mathrm{ml}$ microcentrifuge tube and harvested by centrifugation at 13,200 rpm for $5 \mathrm{~min}$. Genomic DNA was extracted using the Easy-DNA Kit (Invitrogen Corp., Carlsbad, CA), quantified by spectrophotometry at 260 $\mathrm{nm}$, and then standardized to $50 \mathrm{ng} / \mu \mathrm{l}$.

Polymerase chain reaction (PCR) amplification of the ITS1, 5.8S, and ITS2 regions of the ribosomal DNA (rDNA) was performed using primers ITS4 and ITS5 (21). Reactions were $50 \mu \mathrm{l}$ in volume and consisted of $20 \mathrm{mM}$ Tris- $\mathrm{HCl}(\mathrm{pH} \mathrm{8.3),50}$ $\mathrm{mM} \mathrm{KCl}, 1.5 \mathrm{mM} \mathrm{MgCl} 2,200 \mu \mathrm{M}$ each dNTP, $200 \mathrm{nM}$ each primer, $1.5 \mathrm{U}$ of Taq polymerase (Invitrogen), and $50 \mathrm{ng}$ of genomic DNA. Thermal cycling conditions consisted of an initial denaturation step at $95^{\circ} \mathrm{C}$ for $3 \mathrm{~min}$; followed by 33 cycles of $95^{\circ} \mathrm{C}$ for $30 \mathrm{~s}, 58^{\circ} \mathrm{C}$ for $1 \mathrm{~min}$, and $72^{\circ} \mathrm{C}$ for $45 \mathrm{~s}$; and a final extension step at $72^{\circ} \mathrm{C}$ for $2 \mathrm{~min}$. PCR products were purified with a Qiaquick PCR Purification Kit (Qiagen Inc., Valencia, CA). Cycle sequencing reactions were performed using an ABI Prism BigDye Terminator v3.0 Ready Reaction Cycle Sequencing Kit (Applied Biosystems Inc., Foster City, CA). Reactions were cleaned using Centrisep columns (Princeton Separations Inc., Adelphia, NJ), dried, and then submitted to the University of Iowa DNA Sequencing Facility (Iowa City, IA) for electrophoresis and fluorescence analysis.
A variety of Pythium spp. sequences were obtained from GenBank for comparison. All sequences were aligned using the ClustalW algorithm in MegAlign 5.05 (DNASTAR Inc., Madison, WS) and adjusted by visual examination. A phylogenetic tree was constructed in MEGA 2.1 (10) using the neighbor-joining algorithm from genetic distances calculated using the Kimura two-parameter model. Bootstrap values were calculated in MEGA 2.1 based on 1,000 random samples of the data set.

Impact of Pythium species on root growth and survival. Cone-tainers $(3.8 \times$ $20 \mathrm{~cm}$ ) containing sand meeting USGA specifications (19) (BB 205, Golf Agronomics Inc., Rockingham, NC) were

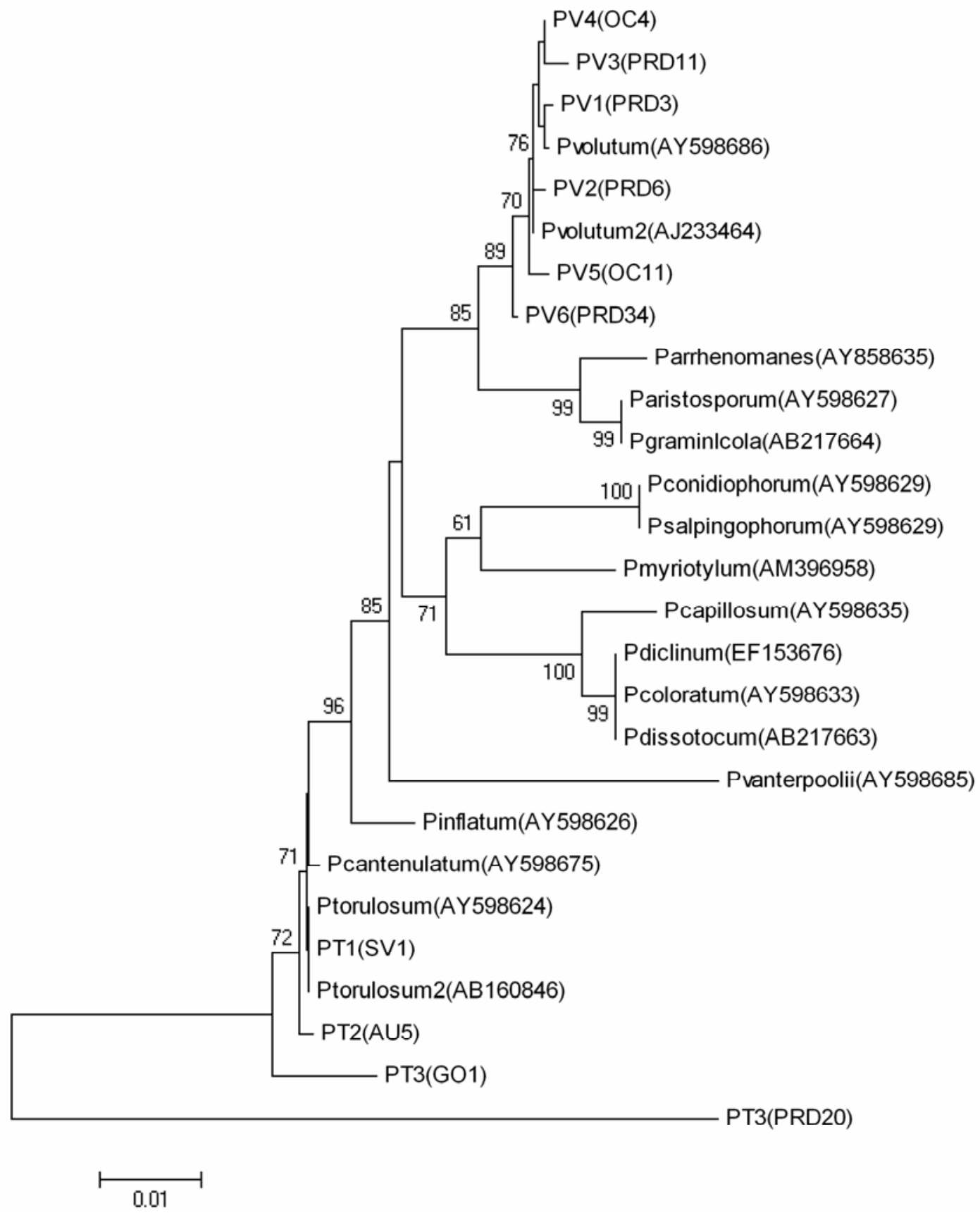

Fig. 2. Neighbor-joining phylogram of Pythium species produced from sequences of rDNA regions ITS1, 5.8S, and ITS2. Scale bar indicates horizontal distance corresponding to genetic distance as calculated by the Kimura 2-parameter model. Bootstrap values are indicated adjacent to the nodes and are based on 1,000 resamplings of the data set. 
seeded with 'A-1' creeping bentgrass (9.7 $\left.\mathrm{g} \mathrm{m}^{-1}\right)$. The Cone-tainers were placed in a greenhouse at $26 / 22^{\circ} \mathrm{C}$ (12-h day/night cycles) and misted twice daily to encourage rapid germination. Following germination, the turf was maintained in the greenhouse by irrigating twice daily with a complete nutrient solution containing $106.23 \mathrm{~mol} \mathrm{~m}^{-3}$ nitrogen, $10.41 \mathrm{~mol} \mathrm{~m}^{-3}$ phosphorus, and $111.03 \mathrm{~mol} \mathrm{~m}^{-3}$ potassium. The turf was trimmed weekly with scissors to a height of $1.27 \mathrm{~cm}$.

Six weeks after seeding, each Cone-tainer was inoculated with sterilized creeping bentgrass leaves infested with one of five $P$. volutum isolates (PRD48, PRD38, PRD39, OC2, and PRD11), one of two P. torulosum isolates (SV3 and PV3), or a co-inoculation of one $P$. volutum and one $P$. torulosum isolate (OC2 and SV3). The inoculum was prepared by placing three to four 3-mm mycelial plugs into sterile water containing five to seven sterilized 1-cm-long creeping bentgrass leaves. The inoculum was incubated under continuous fluorescent light at room temperature $\left(23\right.$ to $\left.25^{\circ} \mathrm{C}\right)$ for 3 days. Inoculations were performed by cutting the root system at a 5-cm depth, the turf plug was removed from the Cone-tainer, the sand in the Cone-tainer was discarded and replaced with fresh sand, five to seven $P y$ thium-colonized grass blades were placed onto the surface of the fresh sand, and then the turf plug was placed on top of the colonized grass blades. An uninoculated control was included in each experiment by cutting the roots at $5 \mathrm{~cm}$, then repotting onto fresh, uninfested sand.
Inoculated Cone-tainers were transferred to a growth chamber and arranged in a completely random design with 10 replications per isolate. Initial growth chamber conditions were 12-h day/night cycles at $24 / 16^{\circ} \mathrm{C}$ to mimic conditions during fall and spring. After 4 weeks, four of the 10 replications were destructively sampled to measure root necrosis, root depth, and root mass. Root necrosis was estimated visually on a scale of 0 to $10(0=$ no necrosis, $10=$ $100 \%$ root necrosis). Root depth was assessed by removing the creeping bentgrass plug from the Cone-tainer and measuring the distance from the soil surface to the deepest root tip. The sand was then thoroughly washed from the root system by gently massaging the roots in deionized water. Pythium isolates were obtained from a 30-mg subsample of freshly washed roots. All isolates were collected by washing the roots for $6 \mathrm{~h}$ in continuously flowing tap water, and four root sections were plated onto SV8 and were identified as described above. Dry root weights were recorded after drying at $60^{\circ} \mathrm{C}$ for $72 \mathrm{~h}$.

The remaining six replicates remained in the growth chamber, in which the temperature was raised to $32 / 26^{\circ} \mathrm{C}$ (day/night) to induce foliar symptoms. The severity of foliar symptoms was assessed at $0,15,23$, 30 , and 38 days after heat exposure using a scale of 0 to 10 , corresponding to the percentage of foliar tissue exhibiting chlorosis or dieback $(0=0 \%, 5=50 \%$, and $10=$ $100 \%)$. After 38 days, all Cone-tainers were destructively sampled to measure root necrosis, root depth, and root mass as described above. Isolations after the 4week heat exposure were performed by plating four washed root sections each on PARP and SV8 as described above. Growth chamber experiments were repeated twice.

All statistical analyses were performed using SAS (version 8.02; SAS Inc., Cary, NC). Analysis of variance was conducted using PROC GLM to estimate the effects of experiment and isolate on disease severity, area under the disease progress curve (AUDPC) (14), root mass (before and after heat exposure), and root depth (before and after heat exposure). Dunnett's $t$ test was used to compare each isolate to the uninoculated control. The Waller-Duncan $k$-ratio $t$ test $(k=100)$ was used to separate means for comparison among $P$. volutum and $P$. torulosum isolates.

\section{RESULTS}

Morphological identification of Pythium species. Most of the Pythium isolates were obtained during the spring and fall of 2003 and 2004, but isolates from Mecklenburg County (location 13) and Moore County were collected in April 2005. Of the 75 Pythium isolates obtained, 59 were identified as $P$. volutum and 16 as $P$. torulosum (Table 1). Isolations were not successful during the summer months and only yielded saprophytes such as Curvularia, Alternaria, Fusarium, and Colletotrichum species. P. volutum was the dominant species isolated at all locations except Guilford County and New Hanover County (Table 1). P. torulosum was isolated from
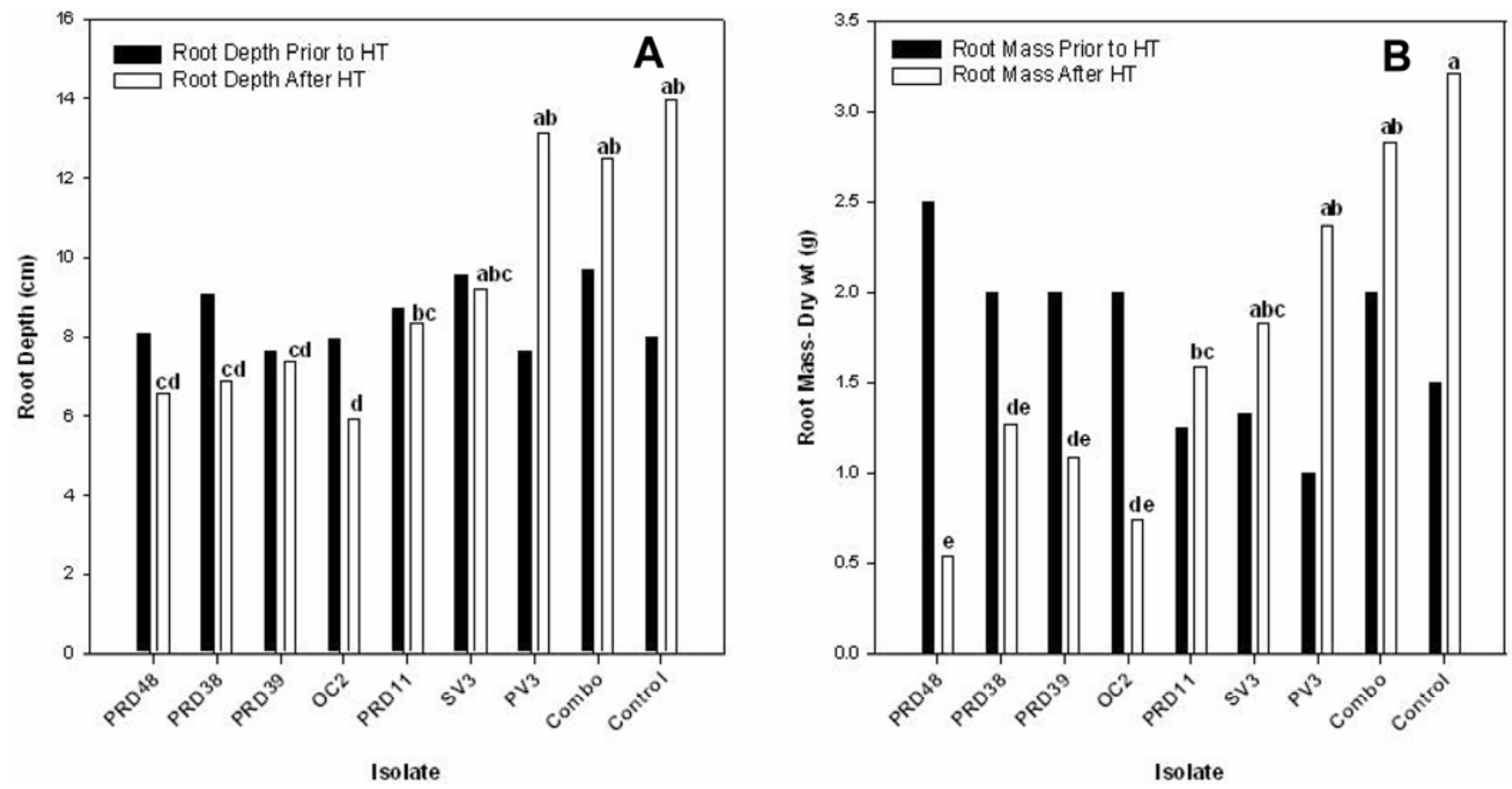

Fig. 3. Impact of Pythium volutum and P. torulosum on A, root depth and B, root mass of creeping bentgrass. White bars represent measurements prior to heat treatment (HT) and black bars represent measurements after 4 weeks of heat treatment. Isolates PRD38, PRD48, PRD39, OC2, and PRD11 are P. volutum, isolates SV3 and PV3 are P. torulosum, and 'co-inoc' represents a co-inoculation of OC2 and SV3. Bars with the same letter are not significantly different according to Waller-Duncan $k$-ratio $t$ test $(k=100)$. 
six of the 14 golf courses sampled and was only obtained when PARP was utilized as the isolation medium (Table 1). P. volutum isolates were characterized by five to seven diclinous antheridia, inflated lobate sporangia, large oospores ( 28 to $31 \mu \mathrm{m}$ ), and a cottony colony morphology on SV8 (Table 2, Fig. 1). An antheridium that coiled around the oogonial stalk was observed in all $P$. volutum isolates (Fig. 1). P. torulosum isolates were characterized by single monoclinous antheridia, inflated lobate sporangia, small oospores (15 to $18 \mu \mathrm{m}$ ), and rosette colony morphology on SV8 (Table 2, Fig. 1).

Phylogenetic analysis using ribosomal DNA sequences. According to internal transcribed spacer (ITS) sequence data, six $P$. volutum haplotypes and four $P$. torulosum haplotypes were identified in the sample population (Table 2 ). The majority of $P$. volutum isolates belonged to the PV4 and PV6 haplotypes, and the majority of the $P$. torulosum isolates belonged to the PT1 and PT2 haplotypes (Table 2). All isolates from this study identified as $P$. volutum were placed in the same clade as the $P$. volutum ITS sequences obtained from GenBank (Fig. 2). Fifteen isolates identified as $P$. torulosum were placed in the same clade as the $P$. torulosum sequences obtained from GenBank (Fig. 2). Isolate PRD20 was identified as P. torulosum based on morphological characters, but this isolate was placed outside of the $P$. torulosum clade.

Impact of Pythium species on root growth and survival. ANOVA detected no significant differences among experiments; therefore data presented are the average of the two experiments. Root and foliar symptoms did not develop during the 4week period at $24 / 16^{\circ} \mathrm{C}$, and root mass and root depth were not negatively impacted by inoculation with $P$. volutum or $P$. torulosum (Fig. 3). Isolations from infected root tissue consistently yielded the inoculated species. Isolations from co-inoculations of $P$. volutum and $P$. torulosum yielded only P. torulosum.

After 15 days of heat exposure, foliar symptoms developed and quickly reached a plateau in the $P$. volutum-infested Cone-tainers (Fig. 4). Foliar symptoms initially appeared as wilt then progressed to chlorosis followed by foliar decline. Beyond 15 days of heat exposure, foliar symptoms declined slightly then remained constant for the duration of the experiment (Fig. 4). All P. volutum isolates were pathogenic toward creeping bentgrass according to Dunnett's $t$ test $(P$ $<0.05)$, and no significant differences were detected among isolates of this species (Fig. 5). In contrast, the two P. torulosum isolates and the co-inoculation treatment did not induce foliar symptoms that were significantly different from the uninoculated control according to Dunnett's $t$ test $(P<0.05)$ (Fig. 5).

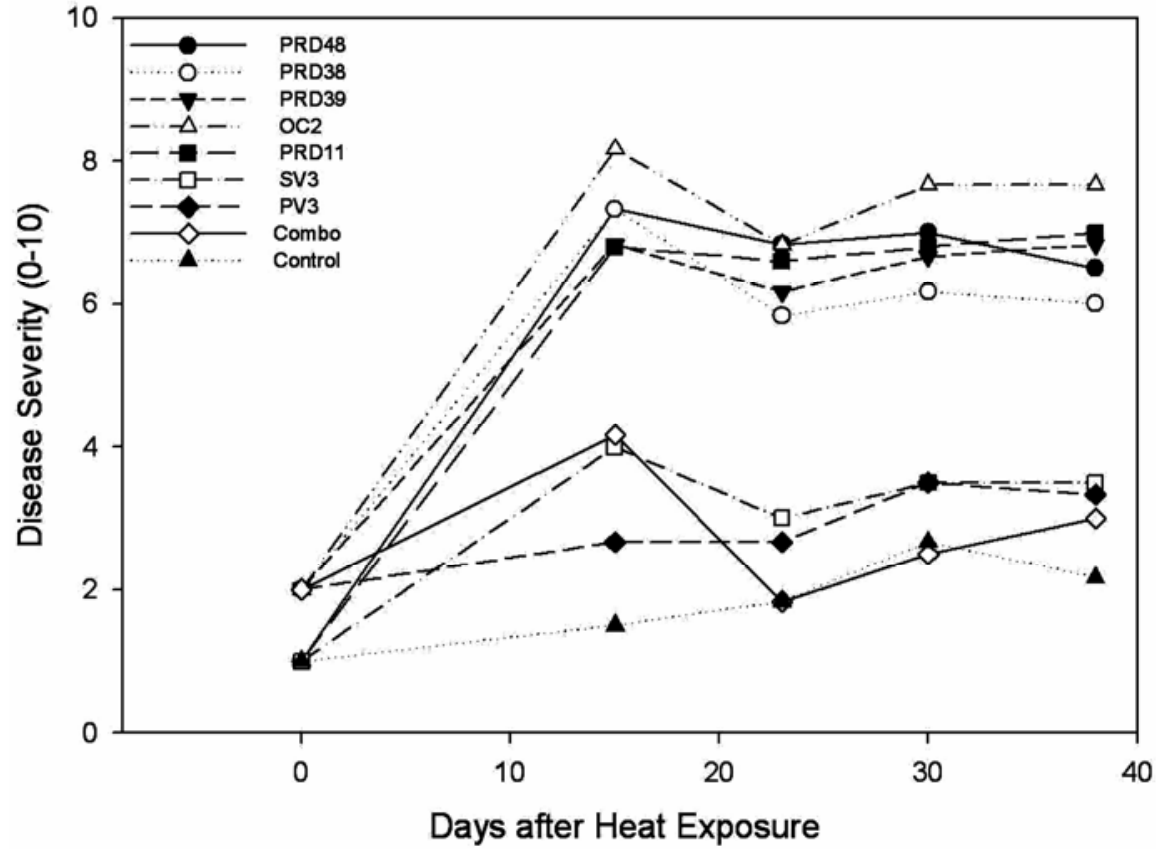

Fig. 4. Virulence of five Pythium volutum isolates, two $P$. torulosum isolates, one co-inoculation, and an uninoculated control. Disease severity was evaluated on a scale of 0 to $10(0=0 \%$ and $10=100 \%)$ based on foliar tissue exhibiting decline. Isolates PRD38, PRD48, PRD39, OC2, and PRD11 are $P$. volutum, isolates SV3 and PV3 are $P$. torulosum, and 'co-inoc' represents a co-inoculation of OC2 and SV3. Bars with the same letter are significantly different according to Waller-Duncan $k$-ratio $t$ test $(k=$ 100).

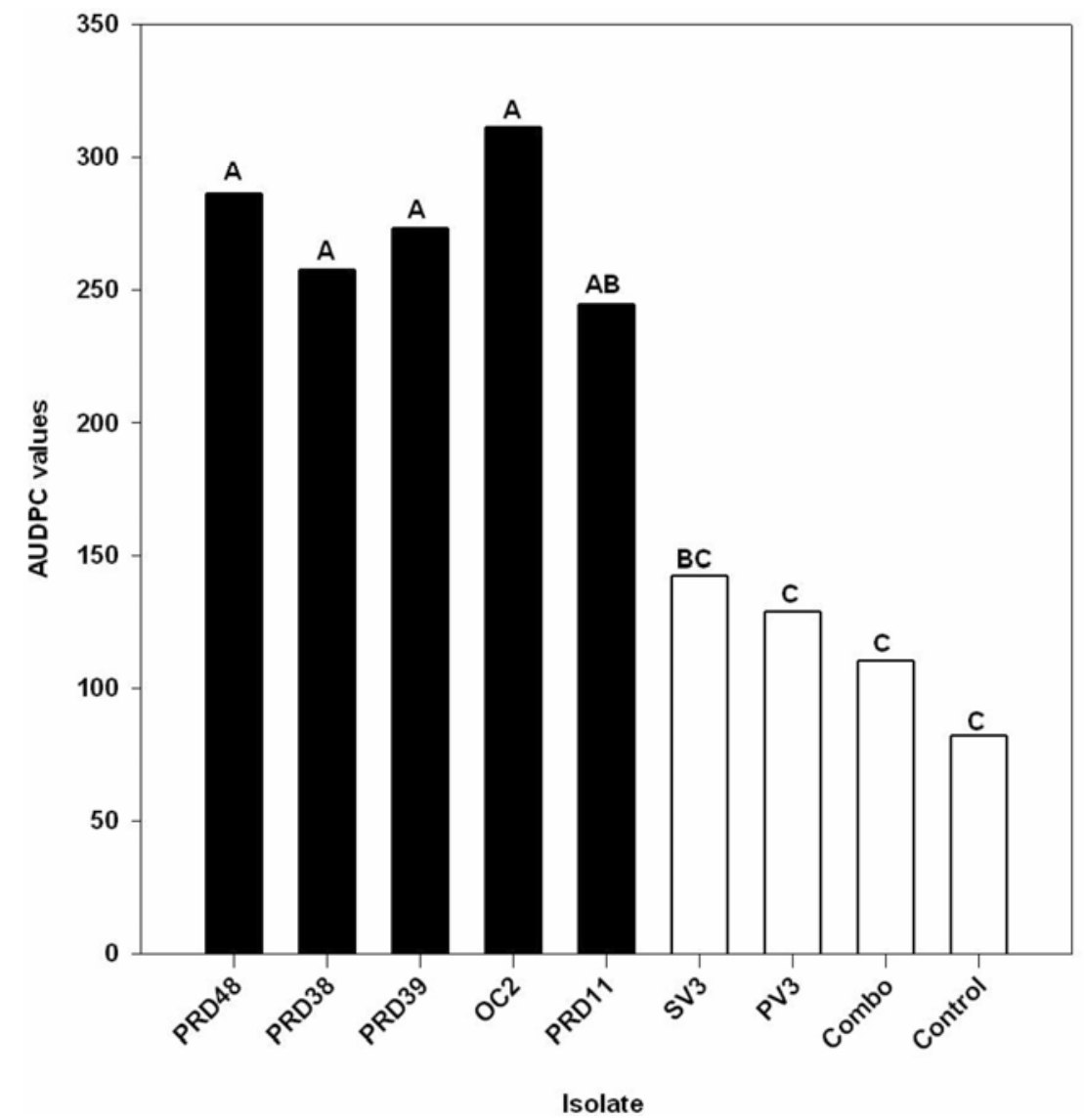

Fig. 5. Area under the disease progress curve (AUDPC) values for five Pythium volutum isolates, two P. torulosum isolates, one co-inoculation, and an uninoculated control. AUDPC values were calculated from disease severity data collected weekly from 4 weeks. Bars with the same letter are not significantly different according to Waller-Duncan $k$-ratio $t$ test $(k=100)$. Isolates PRD38, PRD48, PRD39, OC2, and PRD11 are $P$. volutum, isolates SV3 and PV3 are $P$. torulosum, and 'co-inoc' represents a coinoculation of $\mathrm{OC} 2$ and $\mathrm{SV} 3$. 
During heat exposure, root depth and mass continued to increase in uninoculated Cone-tainers (Fig. 3). According to Dunnett's $t$ test $(P<0.05)$, however, $P$. volutum infections prevented continued root growth, and also caused a slight reduction in root depth and substantial reductions in root mass relative to the measurements taken prior to heat exposure (Fig. 3). Roots from Cone-tainers infested with $P$. volutum had a light tan color, lacked root hairs, and had bulbous root tips. However, significant differences were not detected when root necrosis was visually estimated (data not shown). Four of the five $P$. volutum isolates did not significantly differ in their impact on root depth or root mass (Fig. 3). Creeping bentgrass root growth was not significantly inhibited at high temperatures by $P$. torulosum infections according to Dunnett's $t$ test $(P<0.05)$ (Fig. 3). $P$. volutum was not isolated from root tissue after the 4-week exposure to heat.

\section{DISCUSSION}

The root diseases that attack creeping bentgrass grown in sand-based golf course putting greens remain poorly understood. Since 2002, patch-like symptoms typically indicative of a root disease have been observed in creeping bentgrass across the southeastern United States. Based on these stand symptoms, and the presence of mild necrosis of roots and stolons, many of these cases were initially diagnosed as take-all patch by the Plant Disease and Insect Clinic at North Carolina State and other diagnostic laboratories. Upon further investigation, however, G. graminis var. avenae could not be isolated from the affected turf. Further investigation revealed that at least two diseases were present: summer patch caused by Magnaporthe poae $(16,17)$ and an uncharacterized $P y$ thium disease (18). We later determined that this unknown disease was Pythium root dysfunction caused by P. volutum (9). The present study demonstrates that this pathogen is widespread in North Carolina and is also present in Virginia, South Carolina, and Georgia. Moreover, this study provides important details on the epidemiology of PRD.

$P$. volutum was previously isolated from creeping bentgrass in North Carolina and Maryland and demonstrated to be pathogenic toward creeping bentgrass seedlings $(1,5)$. Yet, it was not isolated more than twice in each study and was not thought to be a widespread, important pathogen. $P$. volutum was isolated 59 times in our study, comprising $79 \%$ of the Pythium isolates obtained. Moreover, P. volutum was isolated from all but two locations, indicating that this species is widely distributed throughout the sampling area. Prior surveys of Pythium species associated with creeping bentgrass roots showed that $P$. torulosum was the most frequently isolated species $(1,5,6,12,13)$. In contrast, we only isolated $P$. torulosum 16 times from six locations. Similar to previous studies $(1,5,12)$, P. torulosum was nonpathogenic to creeping bentgrass roots in our growth chamber experiments.

Previous surveys of Pythium populations in turfgrass roots utilized selective media (PARP) containing the antibiotics ampicillin, rifampicin, pimaricin, and $\mathrm{PCNB}$ $(1,5,12)$. $P$. volutum is documented as a slow-growing species (5), and we have observed that its growth can be further limited by these antibiotics. In this experiment, we were successful in isolating $P$. volutum when roots were washed in running tap water then plated on SV8 or when samples were baited with creeping bentgrass seedlings. Future surveys of Pythium species associated with turfgrass roots should employ these methods in addition to using a selective medium to avoid inadvertently selecting for or against certain species.

$P$. volutum was highly virulent toward creeping bentgrass seedlings in previous experiments at temperatures between 12 and $32^{\circ} \mathrm{C}(1,5)$. Yet, in our experiments, no symptoms occurred on mature creeping bentgrass plants at $24 / 16^{\circ} \mathrm{C}$. Root mass and depth were not adversely affected at cooler temperatures, but once inoculated plants were exposed to extended periods of heat, root growth and survival was severely reduced and foliar symptoms developed. This supports our observations that $P$. volutum infects creeping bentgrass roots in the fall, winter, and spring, causing the plants to be more susceptible to heat or drought stress during the summer. In contrast, Hodges and Coleman (8) and Hodges and Campbell (7) demonstrated that $P$. arrhenomanes and $P$. aristosporum reduced root and shoot mass of creeping bentgrass at $26 / 18^{\circ} \mathrm{C}$. The epidemiology of PRD may vary depending on the Pythium species involved.

Our results demonstrate that $P$. volutum is a widespread pathogen causing PRD of creeping bentgrass in North Carolina and is also present in South Carolina, Virginia, and Georgia. Root infections that occur during cool weather in the fall, winter, and spring induce symptom expression during periods of heat or other stresses. The mechanisms by which symptoms are induced remain unknown. $P$. volutum infections reduced the growth and survival of creeping bentgrass roots during heat exposure, which may lead directly to the expression of symptoms. As Hodges and Coleman (8) speculated, root infections may also hinder water and nutrient uptake. Further research is needed to define the temperatures at which root infection and symptom expression occur so that management practices can be optimized for this important root disease. More research is needed to determine the distribution of this pathogen in the southeastern United States.
ACKNOWLEDGMENTS

This research was supported by grants from the Center for Turfgrass Environmental Research and Education at North Carolina State University and the North Carolina Turfgrass Foundation. The authors thank Z. G. Abad and J. A. Roberts for valuable technical assistance, J. L. Shurtleff and the NCSU Phytotron for providing additional technical assistance and growth chamber space, Bruce Martin for providing isolates, and D. M. Benson and H. D. Shew for their helpful reviews of this manuscript prior to submission.

\section{LITERATURE CITED}

1. Abad, Z. G., Shew, H. D., and Lucas, L. T. 1994. Characterization and pathogenicity of Pythium species isolated from turfgrass with symptoms of root and crown rot in North Carolina. Phytopathology 84:913-921.

2. Chamswarng, C., and Cook, R. J. 1985. Identification and comparative pathogenicity of $P y$ thium species from wheat roots and wheatfield soils in the Pacific Northwest. Phytopathology 75:821-827.

3. Dick, M. W. 1990. Keys to Pythium. College of Estate Management, Whiteknights, Reading, UK.

4. Elliott, M. L. 1993. Association of Magnaporthe poae with a patch disease of creeping bentgrass in Florida. Plant Dis. 77:429.

5. Feng, Y., and Dernoeden, P. H. 1999. Pythium species associated with root dysfunction of creeping bentgrass in Maryland. Plant Dis. 83:516-520.

6. Hendrix, F. F., Campbell, W. A., and Moncrief, J. B. 1970. Pythium species associated with golf turfgrasses in the South and Southeast. Plant Dis. Rep. 54:419-421.

7. Hodges, C. F., and Campbell, D. A. 1994 Infection of adventitious roots of Agrostis palustris by Pythium species at different temperature regimes. Can. J. Bot. 72:378-383.

8. Hodges, C. F., and Coleman, L. W. 1985 Pythium-induced root dysfunction of secondary roots of Agrostis palustris. Plant Dis. 69:336-340.

9. Kerns, J. P., and Tredway, L. P. 2007. First report of Pythium root dysfunction of creeping bentgrass caused by Pythium volutum in North Carolina. Plant Dis. 91:632.

10. Kumar, S., Tamura, K., and Nei, M. 1993. MEGA: Molecular Evolutionary Genetics Analysis Version 2.1. Pennsylvania State University, University Park.

11. Martin, F. N. 1992. Pythium. Pages 39-49 in: Methods for Research on Soilborne Phytopathogenic Fungi. L. L. Singleton, J. D. Mihail, and C. M. Rush, eds. American Phytopathological Society, St. Paul, MN.

12. Nelson, E. B., and Craft, C. M. 1991. Identification and comparative pathogenicity of $P y$ thium spp. from roots and crowns of turfgrasses exhibiting symptoms of root rot. Phytopathology 81:1529-1536.

13. Saladini, J. L., Schmitthenner, A. F., and Larsen, P. O. 1983. Prevalence of Pythium species associated with cottony-blighted and healthy turfgrasses in Ohio. Plant Dis. 67:517-519.

14. Shaner, G., and Finney, R. E. 1977. The effect of nitrogen fertilization on the expression of slow-mildewing resistance in Knox wheat. Phytopathology 67:1051-1056.

15. Smiley, R. W. 1993. Historical perspectives of research on ectotrophic root-infecting pathogens of turfgrasses Pages 1-17 in: Turfgrass Patch Diseases Caused by Ectotrophic RootInfecting Fungi. B. B. Clarke and A. B. Gould, eds. American Phytopathological Society, St. Paul, MN.

16. Tredway, L. P. 2005. First report of summer patch of creeping bentgrass caused by Magnaporthe poae in North Carolina. Plant Dis. 89:204.

17. Tredway, L. P. 2006. Genetic relationships 
among Magnaporthe poae isolates from turfgrass hosts and relative susceptibility of 'Pencross' and 'Penn A-4' creeping bentgrass. Plant Dis. 90:1531-1538.

18. Tredway, L. P., and Martin, S. B. 2003. Stalking new disease in creeping bentgrass. Carolinas Green. Nov-Dec:22-26.
19. Turgeon, A. J. 1999. Turfgrass Management, 5th ed. Prentice Hall, Upper Saddle River, NJ. pp. 49-108.

20. Van der Plaats-Niterink, A. J. 1981. Monograph of the Genus Pythium. Studies in Mycology, vol. 21. Centraalbureau voor Schimmelcultures, Baarn, the Netherlands.
21. White, T. J., Bruns, T., Lee, S., and Taylor, J. 1990. Amplification and direct sequencing of fungal ribosomal RNA genes for phylogenetics. Pages 315-324 in: PCR Protocols: A Guide to Methods and Applications. M. A. Innis, D. H. Gelfand, J. J. Sninsky, and T. J. White, eds. Academic Press, San Diego, CA. 